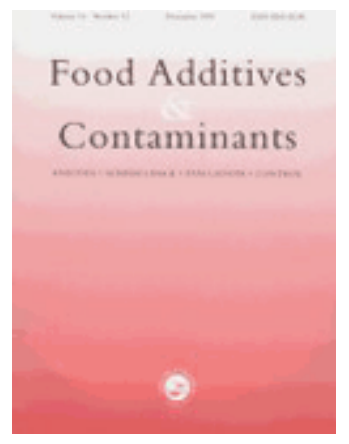

\title{
Comparison of 4 analytical techniques based on atomic spectrometry for the determination of total tin in canned foodstuffs
}

\begin{tabular}{|c|c|}
\hline Journal: & Food Additives and Contaminants \\
\hline Manuscript ID: & TFAC-2010-303.R1 \\
\hline Manuscript Type: & Original Research Paper \\
\hline $\begin{array}{l}\text { Date Submitted by the } \\
\text { Author: }\end{array}$ & 19-Nov-2010 \\
\hline Complete List of Authors: & $\begin{array}{l}\text { BOUTAKHRIT, Khalid; Scientific Institute Of Public Health, FOOD } \\
\text { BOLLE, Fabien; Scientific Institute Of Public Health, Food } \\
\text { CRISCI, Massimo; Scientific Institute Of Public Health, Food } \\
\text { Van Loco, Joris; Scientific Institute Of Public Health, FOOD }\end{array}$ \\
\hline Methods/Techniques: & $\begin{array}{l}\text { Metals analysis - AAS, Metals analysis - ICP, Metals analysis - } \\
\text { ICP/MS }\end{array}$ \\
\hline Additives/Contaminants: & Metals, Trace elements \\
\hline Food Types: & Canned foods \\
\hline
\end{tabular}

\section{SCHOLARONE ${ }^{m}$ \\ Manuscripts}




\title{
Comparison of four analytical techniques based on atomic spectrometry for the determination of total tin in canned foodstuffs
}

\author{
K. BOUTAKHRIT*, M. CRISCI, F. BOLLE and J. VAN LOCO \\ Scientific Institute of Public Health, Section of Food, rue Juliette Wytsman 14, \\ 1050 Brussels, Belgium
}

\begin{abstract}
Different techniques for the determination of total tin in beverages and canned foods by atomic spectrometry were compared. The performance characteristics of Inductively Coupled Plasma - Mass Spectrometry (ICP-MS), Hydride GenerationInductively Coupled Plasma - Atomic Emission Spectrometry (HG-ICP-AES), Electrothermal Atomization - Atomic Absorption Spectrometry (ETA-AAS) and Inductively Coupled Plasma - Atomic Emission Spectrometry (ICP-AES) were determined in term of linearity, precision, recovery, limit of detection, decision limit (CC $\alpha$ ) and detection capability (CC $\beta$ ) (Decision 2002/657/EC). Calibration ranges were covered from $\mathrm{ng} / \mathrm{L}$ to $\mathrm{mg} / \mathrm{L}$ level. Limits of detection ranged from $0.01 ; 0.05 ; 2.0$; $200 \mu \mathrm{g} / \mathrm{L}$ were respectively reached for ICP-MS; HG-ICP-AES; ETA-AAS and ICPAES. Precision, calculated according to ISO 5725-2 for repeatability and within labreproducibility and expressed as relative standard deviation (RSD), ranged from 1.6 to $4.9 \%$ and recovery, based on the decision 2002/657/EC, was found between 95 to $110 \%$. Procedures for the mineralization or extraction of total tin were compared. Wet digestion, sequentially, with nitric acid and hydrogen peroxide provided the best results. The influence of possible interferences present in canned food and in beverage was studied but no interference in the determination of tin was observed.

Since maximum levels for tin established by EU legislation vary from $50 \mathrm{mg} / \mathrm{kg}$ in canned baby foods and infant foods up to $200 \mathrm{mg} / \mathrm{kg}$ in canned food, ICP-AES was chosen as the preferred technique for routine analysis thanks to its good precision, reliability and easy-to-use. The accuracy of this routine method was confirmed by participating in 6 proficiency test schemes with z-scores ranging from -1.9 to 0.6 . Several canned foodstuffs and beverage samples from local market were analysed with this technique.
\end{abstract}

Keywords: Canned food, tin determination, wet digestion, atomic spectrometry 


\author{
* Corresponding author. Tel: +32-2-6425207; fax: +32-2-6425691 \\ E-mail address: Khalid.Boutakhrit@wiv-isp.be
}

\title{
INTRODUCTION
}

For a very long time, precisely since two centuries, tin was the only material for holding foods because it did not influence the taste and flavour of meat and drinks. Today it is well known that canned food contains more or less dissolved tin depending on the $\mathrm{pH}$ of the content, storage temperature, time and presence of nitrates used as fertilizers (Blunden et al. 2003). The exposure of the general population to tin is essentially dietary in origin, coming particularly from the consumption of food stored in cans.

The Expert committee of the FAO and the WHO (JECFA) has established a provisional tolerable weekly intake (PTWI) of $14 \mathrm{mg} / \mathrm{kg} \mathrm{b.w.} \mathrm{(JEFCA} \mathrm{2005)} \mathrm{because}$ they noted that inorganic tin compounds generally have low systemic toxicity due to limited absorption from the gastrointestinal tract and the low accumulation tin in tissues.

The ingestion of canned food highly contaminated with soluble tin compound results in various symptoms: nausea, abdominal cramps, vomiting, headache, diarrhoea and fever (Schäfer et al. 1984). Due to its moderate toxicity, the maximum permissible levels enforced by the European regulation are $50 \mathrm{mg} / \mathrm{kg}$ for infant food, $100 \mathrm{mg} / \mathrm{kg}$ for beverages and $200 \mathrm{mg} / \mathrm{kg}$ for canned solid food (European Commission Regulatory (EC) 2006).

Several analytical methods have been used for the determination of tin in various food matrices. Among these includes X-Ray fluorescence (Yoshiki et al. 2006), spectrophotometry (Gutierrez et al. 1985; Capitán-Vallvey et al. 1994; Huang et al. 1997), neutron activation analysis (NAA) (Vermaercke et al. 2009; Chiba et al. 1994), spectrofluorimetry (Manzoori et al. 2006; Rubio et al. 1985), atomic absorption spectrometry (Knápek et al. 2009; Dogan et al. 1980; Martin et al. 1994), atomic emission spectrometry (Perring et al. 2002; Sumitani et al. 1993; Ribeiro et al. 2003), 
hydride generation (Hanwen et al. 2003; Fang et al. 1992), and electrochemical methods (Ekmekci et al. 2000; Qiong et al. 1999; Clinio et al. 2004).

In this work, we introduce, optimised and validated some atomic spectrometric techniques and we have compared their analytical performance in order to select the most appropriate and reliable technique for routine analysis of tin in canned foodstuffs.

At the beginning and on the basis of the existing methods (Perring et al. 2002; Chiba et al. 1987), we tried to adapt these methods to our objective which is the determination of tin in canned foods.

\section{MATERIALS AND METHODS}

\section{Instrumentation}

ICP-AES and HG-ICP-AES, a Perkin-Elmer (PE) (Norwalk, CT, USA) ICP Optima 4300 DV inductively coupled Ar plasma optical emission spectrometer equipped with an autosampler (AS93 plus, PE) and with a hydride generation (HG) system (FIAS $400 \mathrm{PE})$ with two peristaltic pumps and regulated gas supply. The gas flow rate was set to $40-250 \mathrm{ml} / \mathrm{min}$.

ETA-AAS, a Perkin-Elmer (PE) (Überlingen, Germany) Simultaneous Multi-element atomic absorption spectrometer model SIMAA 6000 equipped with longitudinal Zeeman background correction and a transversely heated graphite atomizer (THGA). A Hallow cathode Lamp was used.

ICP-MS, a Perkin-Elmer (PE) (Ontario, Canada) ICP MS ELAN DRC II inductively coupled Ar plasma mass spectrometer.

Samples for total tin were digested in a drying oven (Binder FD 115, Tuttlingen, Germany), equipped with thermostatisation and an integrated timer.

\section{Chemicals and reagents}

Ultrapure water of $18 \mathrm{M} \Omega / \mathrm{cm}$ specific resistivity was obtained from a Milli- $\mathrm{Q}^{\circledR}$ water system purification (Millipore, Milford, MA, USA). Chemicals for mineralization were Nitric acid $(70 \%(w / w)$, J.T. Baker, USA), hydrogen peroxide $(30 \%(w / w)$, J.T. Baker, 
Deventer, Holland). Hydrochloric acid (37\% (w/w), J.T. Baker, USA) was used to stabilize tin solutions.

HG-ICP-AES, for the flow injection system, $\mathrm{NaBH}_{4} 0.3 \%$ (w/v) solutions were prepared daily by dissolving appropriate amounts of powdered $\mathrm{NaBH}_{4}$ (for cold vapor analysis, J.T. Baker, Holland) in $0.1 \%$ (w/v) NaOH (Pellets, Merck, Germany).

ETA-AAS, for chemicals modifier [ $\left.5 \mu \mathrm{g} \mathrm{Ni}+145 \mu \mathrm{g} \mathrm{H}_{3} \mathrm{PO}_{4}\right]$ was prepared by using $\mathrm{Ni}$ solutions of $1000 \mathrm{mg} / \mathrm{L}$ (atomic spectrometry standard, Perkin-Elmer, USA) and $\mathrm{H}_{3} \mathrm{PO}_{4}(85 \%$ (w/w), Merck, Darmstadt, Germany).

A commercially available $1000 \mathrm{mg} / \mathrm{L}$ Sn standard solution purchased from PerkinElmer, Pure atomic spectrometry standard (Shelton, CT, USA).

Working solutions for Sn were prepared daily by serial dilutions of this stock solution in: $0.5 \%$ (v/v) $\mathrm{HNO}_{3}$ for ICP-MS; $0.1 \mathrm{~mol} / \mathrm{L} \mathrm{HCl}$ for HG-ICP-AES and $1 \mathrm{~mol} / \mathrm{L} \mathrm{HCl}$ for ETA-AAS and ICP-AES.

All solutions containing the potential interfering ions studied were prepared at the required concentrations by adding appropriate amounts of stock solutions (PerkinElmer, Shelton, CT, USA).

Canned food and beverages from proficiency testing exercise was used as: FAPAS S7R54, FAPAS S7R60, FAPAS S7R76, FAPAS S7R85, FAPAS S7R98

All canned foods were purchased from local markets.

\section{Digestion procedures}

After opening the canned food, the contents were transferred into a clean beaker, then samples were homogenized by mechanical mixing with a high-speed blender. Approximately $1.0 \mathrm{~g}$ of canned food wet weight or $1 \mathrm{~mL}$ of canned beverage was taken then was placed in a PFA digestion tube, with $5 \mathrm{ml}$ of concentrated nitric acid. Afterwards, digestion was carried out at temperature of $180^{\circ} \mathrm{C}$ in the oven. After cooling the tubes, $3 \mathrm{ml} \mathrm{H}_{2} \mathrm{O}_{2}$ was added and evaporated to about $0.5 \mathrm{~mL}$. Each digested sample was transferred quantitatively into a $10 \mathrm{ml}$ calibrated tube and setting to volume with hydrochloric acid solution $1 \mathrm{~mol} / \mathrm{L}$. If analysis is carried out 
later, sample solutions must be stored in $6 \mathrm{~mol} / \mathrm{L} \mathrm{HCl}$ to prevent hydrolysis of tin which forming a semi-colloidal suspension.

\section{Analytical procedures}

All measurements were carried out in triplicate (instrument programmed). Detailed operating conditions of analytical set-up are summarised in Table 1 for all studied methods.

HG-ICP-AES, conversion into $\mathrm{SnH}_{4}$ resulted from transporting both the acidified sample solutions in $0.1 \mathrm{~mol} / \mathrm{L} \mathrm{HCl}$ and the reducing agent $\mathrm{NaBH}_{4}$ solution into the manifold block by two peristaltic pumps. Hydride was generated and separated from the gas-liquid mixture in the separator block added to the manifold, and swept with argon into the plasma for atomization and measurement of Sn.

ETA-AAS, autosampler volume of $20 \mu \mathrm{L}$ of sample or standard tin diluted with $\mathrm{HCl} 1$ $\mathrm{mol} / \mathrm{L}$ followed by $5 \mu \mathrm{L}$ of chemical modifier; [5 $\mu \mathrm{g} \mathrm{Ni}$ and $145 \mu \mathrm{g} \mathrm{H}_{3} \mathrm{PO}_{4}$ ] were injected into a pyrolytically coated graphite tubes with inserted pyrolytic graphite L'vov platform. Then a programmed furnace temperature started to charring and atomizing the sample.

ICP-MS, the samples were diluted in $0.5 \%(\mathrm{v} / \mathrm{v}) \mathrm{HNO}_{3}$. Prior to measurement of tin, optimisation of the ICP-MS conditions was achieved by tuning for reduced oxide and doubly charged ion formation with a standard tuning solution.

ICP-AES, sample diluted in $1 \mathrm{~mol} / \mathrm{L} \mathrm{HCl}$ was pumped to the concentric nebulizer. After the sample aerosol is produced, a cyclonic spray chamber was used to allow only very fine droplets to pass to the plasma.

\section{RESULTS AND DISCUSSION}

\section{Optimisation of the ETA-AAS}

The optimum operating conditions for obtaining improved sensitivity for tin in acid digestion medium were determined. The effect of the ashing temperature, ashing time, atomizing temperature and the $\mathrm{HCl}$ concentration were studied. When the ashing was conducted at temperatures ranging from 400 to $1100^{\circ} \mathrm{C}$, we noticed that tin response was stable up to an ashing temperature of $1000^{\circ} \mathrm{C}$. Beyond this value, analyte loss was observed. The ashing time curve was carried out and the Sn signal 
reaches a maximum plateau for time ashing from $30 \mathrm{sec}$, this period time was sufficient to ensure complete calcination of the sample. Similarly, the atomization temperature was investigated from 2000 to $2500^{\circ} \mathrm{C}$, an optimum signal with the best profile and reproducible results was found at $2200^{\circ} \mathrm{C}$. The concentration of $\mathrm{HCl}$ has a little effect on the tin signal in the range from 0.1 to $2 \mathrm{~mol} / \mathrm{L}$, a concentration of 1 $\mathrm{mol} / \mathrm{L} \mathrm{HCl}$ was selected to prevent hydrolysis of tin solution and to increase the lifetime of the graphite furnace tube. Several chemical modifiers were tested (Table. 2).The best one, given a well defined and sharp peak with negligible background absorbance, was composed of a mixture of $\mathrm{Ni}$ and $\mathrm{H}_{3} \mathrm{PO}_{4}$. The nickel solution stabilized the tin and prevented its loss during the charring step.

\section{Optimisation of the HG-ICP-AES}

The efficiency of stannane $\left(\mathrm{SnH}_{4}\right)$ production is a combined function of the used acid, its concentration and the sodium-tetrahydroborate $\left(\mathrm{NaBH}_{4}\right)$ concentration. Different experiments were carried out to study the effect of $\mathrm{NaBH}_{4}$ concentration on the tin signal. From $0.25 \% \mathrm{NaBH}_{4}$, the signal reaches an optimum plateau. The concentration of $0.3 \% \mathrm{NaBH}_{4}$ was chosen as working condition.

The effect of $\mathrm{HCl}$ concentration was evaluated by varying the concentration from 0.05 to $0.4 \mathrm{~mol} / \mathrm{L}$. The concentration of $\mathrm{Sn}$ decreases constantly. The $\mathrm{Sn}$ signal was more or less stable within the range from 0.05 to $0.1 \mathrm{~mol} / \mathrm{L}$. Out of this range, the response decrease rapidly. Strict control should be required because small changes around the maximum value may produce a severe decrease in sensitivity. The effect of the argon gas flow used as the carrier gas on the tin signal was also studied. An argon flow of $225 \mathrm{~mL} / \mathrm{min}$ was selected as optimum.

\section{Optimization of the ICP-AES}

The emission line wavelength $189.927 \mathrm{~nm}$ was selected because it gave the best signal to background ratio, compared to other emission lines, and was found to be robust enough with respect to interferences.

The stability of tin solution was tested versus time of storage and the variation of the slope was not significant during the time of study.

\section{Optimization of the ICP-MS}


Determination of tin was carried out with the major isotope ${ }^{120} \mathrm{Sn}$ which provides a high and sensitive signal and no interferences are present compared to other isotopes as $116 ; 117 ; 118$ and 119 amu.

Standards and samples solutions were prepared in $0.5 \% \mathrm{HNO}_{3}$ because there is no risk of tin hydrolysis at $\mathrm{ng} / \mathrm{L}$ level.

\section{Analytical performance and validation}

The 4 techniques were evaluated on their analytical performances.

\section{Calibrations curves}

The experiments were carried out under the conditions described before. Five standards of $S n$ were used for each techniques ranging from $n g / L$ level for ICP-MS, $\mu \mathrm{g} / \mathrm{L}$ for HG-ICP-AES and ETA-AAS, mg/L level for ICP-AES. The calibration range, the slope, the correlation coefficient are summarised in table 3. All calibration lines were linear within their calibration range (correlation coefficient $R^{2}>0.999$ ).

\section{The detection limit}

The detection limit (LOD) was calculated on the basis of the matrix blank mean concentration (fresh vegetables, beverages and baby food without the analyte), added to three times the standard deviation of 10 matrix blanks. The limit of quantification (LOQ) was calculated similar as the LOD except with six times the standard deviation. Corresponding methodological detection limits for tin in canned food as determined by ICP-MS, HG-ICP-AES, ETA-AAS and ICP-AES are $0.1 \mu \mathrm{g} / \mathrm{kg}$, $0.5 \mu \mathrm{g} / \mathrm{kg}, 20 \mu \mathrm{g} / \mathrm{kg}$ and $2 \mathrm{mg} / \mathrm{kg}$ respectively.

\section{Precision}

The precision of the methods, repeatability and within lab-reproducibility, were determined following the European decision 2002/657/EC (European Commission decision 2002) and were calculated according to the ISO 5725-2 (NBN ISO 5725-2). The repeatability and within lab-reproducibility results, expressed as relative standard deviation, are shown in table 3. The ICP-AES method provides a good precision since it is mainly due to ruggedness of the ICP system. The HG-ICP-AES and ETAAAS give similar values of reproducibility. ICP-MS technique was less precise in comparison with the others techniques. 
The uncertainty of the measurement was also determined by statistical analysis of data according to ISO 5725-2 and expressed in percentage. We noticed that ICP-MS method provides a more dispersed results than the other methods due partly to the high dilution of the samples.

\section{Trueness and recovery}

The trueness was also assessed by analysis of FAPAS S7R54 sample by these techniques, the assigned value is $(227 \pm 16) \mathrm{mg} / \mathrm{kg}$. The results obtained for all techniques, shown in table 3 , are in good agreement with the reference value except for the ICP-MS which is less accurate compared to the other methods.

To complete the accuracy study, recoveries, based on the decision 2002/657/EC, were measured after spiking with tin at different concentrations. The obtained values (table 3) range from 95 to $110 \%$. These results evidence the absence of matrix effect.

\section{Decision limit and detection capability}

The decision limit (CC $\alpha)$ and the detection capability $(C C \beta)$ were established according to ISO 11843 (ISO 11843-1). The obtained values, corresponding to the maximum limit (MRL) for each product, are shown in table 3. Both the ICP-MS and HG-ICP-AES techniques showed similar results of CC $\alpha$ and CC $\beta$ for all MRLs. ICPAES technique, with the ETA-AAS, provide better results for all MRLs except for canned food where the values provided by ETA-AAS technique are higher.

Experiments were performed to check if the described techniques are susceptible to interferences from elements present in canned foodstuffs. The effect of major elements $\mathrm{K}$ and $\mathrm{Na}(500 \mathrm{mg} / \mathrm{L}), \mathrm{Ca}$ and $\mathrm{P}(250 \mathrm{mg} / \mathrm{L}), \mathrm{Mg}(100 \mathrm{mg} / \mathrm{L}))$ and minor elements ( $\mathrm{Co}, \mathrm{Cr}, \mathrm{Cu}, \mathrm{Fe}, \mathrm{Ni}, \mathrm{Zn} . .$. at $50 \mathrm{mg} / \mathrm{L}$ ) was evaluated and no interferences on the determination of tin was observed in any of the techniques under investigation.

\section{Application to canned foodstuffs samples}

From the evaluation of the analytical performance of the techniques under investigation (precision, accuracy, CC $\alpha$ \& CC $\beta$ ), ICP-AES is more suitable method for the determination of tin in canned foodstuffs in terms of robustness and financial cost of consumables. HG-ICP-AES technique has many inconvenient aspects; it required the optimisation of several parameters, a lot of reagents are used, it is also 
cumbersome and required a well-qualified analyst. ETA-AAS can be used but also has some disadvantages comparing always to ICP-AES as the time of analysis and the life span of the graphite furnace which is reduced due to the use of hydrochloric acid and high atomization temperature. With regard to ICP-MS, this technique works at ppt level and in our case, samples must be diluted about $10^{6}$ times. Therefore, an overestimation of the tin content is possible.

Several canned food and beverage matrices (fruit, vegetables, meat, fish, dairy product, baby food, beverages and juices) from local market were analyzed for total tin content by this method (ICP-AES) and none of its have exceed the MRL (table 4). High concentrations of tin were found mainly in canned fruit like pineapple, mango, fruit cocktail, peeled tomatoes and low content, less than LOD, was observed for the other categories of canned food.

Since maximum levels for tin established by European regulation is high and ranges from 50 to $200 \mathrm{mg} / \mathrm{kg}$, ICP-AES is appropriate as well for this type of analysis and can be chosen as the preferred technique for routine analysis thanks to its good analytical performance, reliability and ease-of-use.

To confirm the reliability of this method, we have participated in many proficiency test schemes for the determination of tin, with the routine technique ICP-AES, in vegetables and fruit juices (from FAPAS), all the results were satisfactory with zscores varying from -1.9 to 0.6 (table 5). From this study, we concluded that atomic spectrometry methods are reliable and still, up to this time, a good tool to determine tin in canned foodstuffs.

\section{CONCLUSIONS}

From the comparison between the four techniques it can be concluded that ICP-AES is the preferred technique for the analysis of $\mathrm{Sn}$ in canned foodstuffs. ICP-AES is an accurate technique showing good trueness and precision. The detection limits are significantly lower than the legal limits for $S n$ in canned foodstuffs. The method has several advantages compared to HG-ICP-AES, ICP-MS and ETA-AAS. The investment of the technique can be advantageousin the long-term since the costs of consumables are reduced. 


\section{REFERENCES}

Blunden S, Wallace T. 2003. Tin in canned food: a review and understanding of occurrence and effect. Food and Chemical Toxicology 41: 1651-1662.

Capitán-Vallvey LF, Valencia MC, Mirón G. 1994. Flow-injection method for the determination of tin in fruit jueces using solid-phase spectrophotometry. Anal. Chim. Acta 289: 365-370.

Chiba M, lyengar V, Greenberg R Robert, Gills T. 1994. Determination of tin in biological materials by atomic absorption spectrophotometry and neutron activation analysis. The Sci. of Total Environ. 148: 39-44.

Chiba M. 1987. Determination of Tin in Biological Materials by Atomic Absorption Spectrometry with a graphite Furnace. J. of Analytical Toxicology 11: 125-130.

Clinio L, Giancarlo T. 2004. Simultaneous square wave anodic stripping voltammetric determination of $\mathrm{Cr}, \mathrm{Pb}, \mathrm{Sn}, \mathrm{Sb}, \mathrm{Cu}, \mathrm{Zn}$ in the presence of reciprocal interference: application to metal matrices. Microchem. J. 78: 175-180.

Dogan S, Haerdi W. 1980. Determination of Total Tin in Environmental Biological and Water Samples by Atomic Absorption Spectrometry with Graphite Furnace. Intern. J. Environ. Anal. Chem. 8: 249-257.

Ekmekci G, Inam R, Somer G. 2000. Differential Pulse Polarographic Behavior of Selenite and Its Application to Determination of Tin in Canned Food. Analytical Sciences 16: 1151-1155.

European Commission Regulatory (EC) No 1881/2006. setting maximum levels for certain contaminants in foodstuffs. Official Journal of the Communities L364, 20, 19 December.

European Commission Decision 2002/657/EC. Implementing Council Directive 96/23/EC, Official Journal of the European Communities, L 221, 27, 12 August.

Fang Z, Sun L, Hansen EH, Olesen JE, L. Henriksen LM. 1992. The determination of trace amounts of Tin by flow-injection hydride generation atomic-absorption 
spectrometry with on-line ion-exchange separation and preconcentration. Talanta 39: 383-390.

Gutierrez AM, Perez-Conde C, Rebollar MP, Polo Diez LM. 1985. A rapid extractive spectrophotometric method for the determination of tin in canned foods with 5,7dichloro-8-quinolinol. Talanta 32: 927-929.

Hanwen S, Shuxuan L, Jing H, Weijun K. Derivative hydride generation atomic absorption spectrometric determination of tin at sub- $\mu \mathrm{gL}^{-1}$ in water samples. 2003. China. Available from: http://www.chemistrymag.org/cji/2003/053023pe.hrm

Huang X, Zhang W, Han S, Wang X. 1997. Determination of tin in canned Foods by UV/visible spectrophotometric technique using mixed surfactants. Talanta 44: 817822.

ISO 11843-1. 2003. Capability of detection, Part 1: terms and definitions, ISO Genova.

Joint FAOMHO Expert Committee on Food Additives (JECFA). Summary and conclusions of the sixty-fourth meeting of 8-17 February. 2005. Rome. Available from: http://www.fao.org/es/esn/jefca/index_en.stm

Knápek J, Herman V, Buchtová R, Vošmerová D. 2009. determination of Tin in Canned Foods by Atomic Absorption Spectrometry. Czech J. Food Sci. 27: 407-409.

Manzoori JL, Amjadi M, Abolhasani D. 2006. Spectrofluorimetric determination of tin in canned foods. J. of Hazardous Materials B 137: 1631-1635.

Martín AM, Sánchez M, Espinosa P, Bagur G. 1994. Determination of Tin in Canned Fruits and Vegetables by Atomic Absorption Spectometry and Liquid-Liquid Extraction. J. AOAC Int. 77: 1627-1630.

NBN ISO 5725-2. 1994. Accuracy (trueness and precision) of measurement methods and results part 2. Belgian Institute of Standardization. 
Perring L, Basic-Dvorzak M. 2002. Determination of total tin in canned food using inductively coupled plasma atomic emission spectroscopy. Anal. Bioanal. Chem. 374: 235-243.

Qiong L, Guanghan L, Heng W, Xiaogang W. 1999. Determination of trace tin in foods by single-sweep polarography. Food Chem. 64: 129-132.

Ribeiro AS, Moretto AL, Arruda MAZ, Cadore S. 2003. Analysis of Powdered Coffee and Milk by ICP OES after Treatment with Tetramethylammonium Hydroxide. Microchim. Acta 141: 149-155.

Rubio S, Gómez-Hens A, Valcárcel M. 1985. Fluorimetric determination of tin at the nanograms per millilitre level in canned beverages. Analyst 110: 43-45.

Schäfer SG, Femfert U. 1984. Tin-A Toxic Heavy Metal? A Review of the Literature. Regulatory Toxicology and Pharmacology 4: 57-69.

Sumitani H, Suekane S, Nakatani A. 1993. Inductively Coupled Plasma Atomic Emission Spectrometric Determination of Tin in Canned Food. J. AOAC Int. 76: 1374-1377.

Vermaercke P, Farina F, Sneyers L, Bruggeman M, Bouças JG. 2009. Validation of the determination of tin by $\mathrm{k}_{0}$-instrumental neutron activation analysis in foodstuff. J. Radioanal. Nucl. Chem. 281: 35-39.

Yoshiki M. 2006. Determination of Tin in Canned Foods by X-Ray Fluorescence Spectrometry. J. of Health Science 52: 67-72. 


\begin{tabular}{|c|c|c|c|c|}
\hline Methods & ICP-MS & HG-ICP-AES & ETA-AAS & ICP-AES \\
\hline Instruments & ELAN DRC II, Perkin-Elmer & $\begin{array}{l}\text { ICP Optima } 4300 \text { DV coupled to } \\
\text { FIAS } 400 \text { Perkin-Elmer }\end{array}$ & SIMAA 6000, Perkin-Elemer & $\begin{array}{l}\text { ICP Optima } 4300 \text { DV Perkin- } \\
\text { Elemer }\end{array}$ \\
\hline $\begin{array}{l}\text { Experimental } \\
\text { conditions }\end{array}$ & $\begin{array}{l}\text { Isotope: }{ }^{120} \mathrm{Sn} \\
\text { Blank: } 0.5 \% \text { HNO3 ultrapur } \\
\text { Nebulizer gas flow: } 940 \mathrm{~mL} / \mathrm{min} \\
\text { Aux. Argon flow: } 1200 \mathrm{~mL} / \mathrm{min} \\
\text { Plasma gas flow: } 15000 \mathrm{~mL} / \mathrm{min} \\
\text { ICP RF Power: } 1100 \mathrm{w}\end{array}$ & $\begin{array}{l}\lambda=189.927 \mathrm{~nm} \\
\text { Blank: } \mathrm{HCl} 0.1 \mathrm{~mol} / \mathrm{L} \\
0.3 \% \mathrm{NaBH}_{4} \text { in } 0.1 \% \mathrm{NaOH} \\
\text { Argon carrier flow: } 225 \mathrm{~mL} / \mathrm{min} \\
\text { Sample Flow: } 3.0 \mathrm{~mL} / \mathrm{min} \\
\mathrm{NaBH}_{4} \text { flow: } 2.6 \mathrm{~mL} / \mathrm{min}\end{array}$ & $\begin{array}{l}\lambda=286.3 \mathrm{~nm} \\
\text { Blank: } \mathrm{HCl} 1 \mathrm{~mol} / \mathrm{L} \\
\mathrm{T}^{\circ} \text { drying: } 130^{\circ} \mathrm{C} \mathrm{t:} 30 \mathrm{sec} . \\
\mathrm{T}^{\circ} \text { ashing: } 850{ }^{\circ} \mathrm{C} \text { t: } 30 \mathrm{sec} . \\
\mathrm{T}^{\circ} \text { atomizing: } 2200^{\circ} \mathrm{C} \text { t: } 10 \mathrm{sec} . \\
\text { Tube cleaning } \mathrm{T}^{\circ}: 2600^{\circ} \mathrm{C} \\
\text { Modifiers: } 5 \mu \mathrm{g} \mathrm{Ni}+145 \mu \mathrm{g} \mathrm{H}_{3} \mathrm{PO}_{4}\end{array}$ & $\begin{array}{l}\lambda=189.927 \mathrm{~nm} \\
\text { Blank: } \mathrm{HCl} 1 \mathrm{~mol} / \mathrm{L} \\
\text { Nebulizer gas flow: } 500 \mathrm{~mL} / \mathrm{min} \\
\text { Aux. Argon flow: } 200 \mathrm{~mL} / \mathrm{min} \\
\text { Plasma gas flow: } 15000 \mathrm{~mL} / \mathrm{min} \\
\text { ICP RF Power: } 1400 \mathrm{w}\end{array}$ \\
\hline
\end{tabular}

Table 1. Optimized working conditions for the atomic spectrometric methods. 


\begin{tabular}{|c|c|}
\hline Matrix modifier & Absorbance \\
\hline $3 \mu \mathrm{g} \mathrm{Mg}+5 \mu \mathrm{g} \mathrm{Pd}$ & 0,0555 \\
\hline $100 \mu \mathrm{g} \mathrm{NH}_{4}{ }^{+}$ & 0,0987 \\
\hline $10 \mu \mathrm{gd}$ & 0,1241 \\
\hline $5 \mu \mathrm{g} \mathrm{Ni}+145 \mu \mathrm{g} \mathrm{H}_{3} \mathrm{PO}_{4}$ & 0,1300 \\
\hline $5 \mu \mathrm{g} \mathrm{Ni}+145 \mu \mathrm{g} \mathrm{H}_{3} \mathrm{PO}_{4}+25 \mu \mathrm{g}$ ascorbic acid & 0,1392 \\
\hline
\end{tabular}

Table 2. Effect of different matrix modifiers on the peak absorbance of tin

\begin{tabular}{|c|c|c|c|c|}
\hline Validation data & ICP-MS & HG-ICP-AES & ETA-AAS & ICP-AES \\
\hline Calibration range $(\mu \mathrm{g} / \mathrm{L})$ & $0.05-1.0$ & $1.0-20$ & $10-100$ & $500-5000$ \\
\hline Slope $($ count $/ \mu \mathrm{g} / \mathrm{L})$ & 7870 & 1154 & $\begin{array}{c}0.00113 \\
(\mathrm{Abs} / \mu \mathrm{g} / \mathrm{L})\end{array}$ & 141.22 \\
\hline $\begin{array}{l}\text { Coefficient of } \\
\text { Correlation }\left(\mathrm{R}^{2}\right)\end{array}$ & 0.99988 & 0.99925 & 0.99987 & 0.99972 \\
\hline LOD \& LOQ $(\mu \mathrm{g} / \mathrm{L})$ & $0.01 \& 0.02$ & $0.05 \& 0.1$ & $2 \& 5$ & $200 \& 300$ \\
\hline Repeatability (\%) & 4.9 & 3.5 & 1.7 & 1.6 \\
\hline Reproducibility (\%) & 7.2 & 4 & 4.7 & 3 \\
\hline Uncertainty (\%) & 19.3 & 8 & 13.2 & 11.3 \\
\hline Recovery (\%) & $100-110$ & $95-104$ & $101-107$ & $98-109$ \\
\hline $\begin{array}{l}\text { Trueness }(\%) \\
\text { Obtained results }(\mathrm{mg} / \mathrm{kg})\end{array}$ & $\begin{array}{c}110.6 \\
(251 \pm 48)\end{array}$ & $\begin{array}{c}99.1 \\
(225 \pm 18)\end{array}$ & $\begin{array}{c}101.8 \\
(231 \pm 30)\end{array}$ & $\begin{array}{c}104.4 \\
(237 \pm 26)\end{array}$ \\
\hline $\begin{array}{c}\text { CC } \alpha \text { \& CC } \beta \text { for MRL: } \\
\text { Baby food: } 50 \\
\text { Beverages: } 100 \\
\text { Canned food: } 200\end{array}$ & $\begin{array}{c}56 \& 63 \\
110 \& 121 \\
218 \& 235 \\
\end{array}$ & $\begin{array}{c}56 \& 62 \\
110 \& 119 \\
218 \& 236 \\
\end{array}$ & $\begin{array}{c}53 \& 57 \\
106 \& 112 \\
222 \& 245\end{array}$ & $\begin{array}{c}52 \& 53 \\
107 \& 113 \\
206 \& 213 \\
\end{array}$ \\
\hline
\end{tabular}

Table 3. Validation data of tin determination by atomic spectrometric methods. The trueness was assessed by analysis of FAPAS S7R54 sample, the assigned value is $(227 \pm 16) \mathrm{mg} / \mathrm{kg}$. 


\begin{tabular}{|c|c|c|c|}
\hline Categories & Canned products & $\begin{array}{c}\text { Tin content } \\
(\mathrm{mg} / \mathrm{kg})\end{array}$ & $\begin{array}{c}\text { Range } \\
\text { (mg/kg) }\end{array}$ \\
\hline Fruits & $\begin{array}{c}\text { Mango slices } \\
\text { Fruit cocktail } \\
\text { Pineapple slices } \\
\text { Apricot halves } \\
\text { Pear halves } \\
\text { Peach halves } \\
\text { Peeled tomato pieces }\end{array}$ & $\begin{array}{c}148 \\
103 \\
63 \\
48 \\
46 \\
44 \\
41\end{array}$ & $41-148$ \\
\hline Vegetables & $\begin{array}{c}\text { Mushroom } \\
\text { Asparagus } \\
\text { Spinach } \\
\text { Green bean } \\
\text { Haricot bean } \\
\text { Maize } \\
\text { Potatoes } \\
\text { Carrots } \\
\text { Garden pea }\end{array}$ & $\begin{array}{l}11 \\
<2 \\
<2 \\
<2 \\
<2 \\
<2 \\
<2 \\
<2 \\
<2\end{array}$ & $<2-11$ \\
\hline Meat & $\begin{array}{l}\text { Corned beef } \\
\text { Sausages }\end{array}$ & $\begin{array}{l}<2 \\
<2\end{array}$ & $<2$ \\
\hline Fishes & $\begin{array}{l}\text { Tuna } \\
\text { Sardines } \\
\text { Mackerel } \\
\text { Salmon } \\
\text { Mussel } \\
\text { Crab } \\
\text { Octopus } \\
\text { Squids }\end{array}$ & $\begin{array}{l}<2 \\
<2 \\
<2 \\
<2 \\
<2 \\
<2 \\
<2 \\
<2\end{array}$ & $<2$ \\
\hline Beverages and juices & $\begin{array}{c}\text { Tomato soup } \\
\text { Vegetables juice } \\
\text { Sparkling water } \\
\text { Lemonades } \\
\text { Iced tea } \\
\text { Energy drinks } \\
\text { Orange juices } \\
\text { Beers }\end{array}$ & $\begin{array}{l}<2 \\
<2 \\
<2 \\
<2 \\
<2 \\
<2 \\
<2 \\
<2\end{array}$ & $<2$ \\
\hline Dairy products & $\begin{array}{l}\text { Concentrated milk } \\
\text { Rice pudding }\end{array}$ & $\begin{array}{l}<2 \\
<2\end{array}$ & $<2$ \\
\hline Baby foods & Baby foods & $<2$ & $<2$ \\
\hline
\end{tabular}

Table 4. Tin levels in canned food from local market determined by ICP-AES. 


\begin{tabular}{|c|c|c|c|c|}
\hline Test materials & Matrices & Assigned value (mg/kg) & Found value & z-score \\
\hline FAPAS S7R54 & Tomato puree & 227 & 237 & 0.6 \\
\hline LGC 7161 & Tomato puree & 225 & 225 & Not given \\
\hline FAPAS S7R60 & Fruit juice & 120 & 122 & 0.3 \\
\hline FAPAS S7R76 & Fruit juice & 100.7 & 85.2 & -1.9 \\
\hline FAPAS S7R85 & Vegetable puree & 112 & 109.7 & -0.3 \\
\hline FAPAS S7R98 & Vegetable puree & 214 & 190 & -1.6 \\
\hline
\end{tabular}

Table 5. Results of the proficiency test scheme for total tin determined by ICP-AES. 
